\title{
Studying Effective Factors on Employees Empowerment of Headquarters of Islamshahr Municipality
}

\author{
Mohamad Reza Zereshki ${ }^{1}$ \\ Azita Zand $2^{*}$ \\ Masoumeh Arfaee ${ }^{3}$ \\ 1- M.S Student in Agriculture Management, Department of Agriculture ,Islamshahr Branch, Islamic Azad University, Tehran, Iran \\ 2- Assistant Professor of Agricultural Extension \& Education,Department of Agriculture, ,Islamshahr Branch \\ Islamic Azad University, Tehran, Iran; Email: azitazand@iiau.ac.ir(corresponding authors) \\ 3-- Assistant Professor of Agricultural Extension \& Education,Department of Agriculture, Ashtian Branch \\ Islamic Azad University, Tehran, Iran; M.Arfaee@gmail.com
}

Doi:10.5901/mjss.2015.v6n6p67

\section{Abstract}

\begin{abstract}
The objective of this research is Studying Effective Factors on Employees Empowerment Employees of Headquarters of Islamshahr Municipality. This is descriptive-correlation research with survey method. This research with respect to objective is regarded as applied research. Statistical society of this research is all employees of headquarters of Islamshahr municipality. In this research 120 persons were selected as volume sample by using class sampling method. The tool for collecting data was questionnaire and Alpha Cronbach of 0.90. In order analyze data, it was benefit from descriptive and inferential statistics. Results of comparing relationship between organizational commitment and Employees empowerment index reveal that there is significant relationship between decision making of employees at headquarters of Islamshahr municipality for partnership and organizational commitment. Coefficient of change at educational indices in relation to priority of educational indices reveal that completed courses are practical and are compatible with job requirements and education received at university, so that employees believe it leads to improving empowerment and job satisfaction. Results of $F$ show that there is significant relationship between organizational commitment and following indices including: job compatibility, experience, being informed of subsidiary affairs, status of required skills, regular supervision, economic status, report, partnership at decision making, appropriate salary and arrangement of activities.
\end{abstract}

Keywords: Prioritizing, Enabling, Headquarter Employees, Municipality, Islamshahr

\section{Introduction}

Nowadays, each organization benefit from different methods for improving abilities of its human workforces. Employees Empowerment is a modern method for increasing productivity through improving commitment of employees toward organization and vice versa. This is valuable method for obtaining balance between complete control of management and freedom of action of employees. Employees Empowerment establishes balance between 2 aforesaid factors, principal and subsidiary objectives of organization that finally leads to promotion of organization and its employees (Talebian and Vafaei 2009, Taherpour and et al 2010). Furthermore, successful managers and organizations require having employees working within framework of human resources and knowledge of managers is among most important issue for obtaining to objectives (Mohades Kasaei 2008). Therefore, The present study purpose was to investigate the effective Factors which might influence Employees Empowerment Employees of Headquarters in municipality of Islamshahr. By casting light on these factors, respective administrators and managers can select more powerful, capable work forces which, in turn, leads to better and more beneficial results.

\section{Literature Review}

As it was already mentioned, the current study aims at shedding light on the factors that might significantly affect the Employees Empowerment Employees of Headquarters in municipality of Islamshahr. Whereas municipality is among main basics of urban management and is required to continuously keep in touch with citizens to meet their requirements, therefore, improving quality of serving and promoting level of service leads to better performance of employees working 
at municipality. One of the main objectives of urban managers at Islamshahr municipality is promotion of topic of Employees empowerment. (Ebrahim Hajizadeh and et al 2010).

Mohammadi (2001) in a research with title of evaluating Employees empowerment of Birjand University announced that job enrichment, delegating power, performance based bonus, partnership management, establishing working team as principal methods of enabling.

Mirkamali and et al (2010) on studying influence of short term full-time and correspondent courses on social Employees empowerment and concluded that short term full-time course is more effective than short term correspondence course with respect to social empowerment and 4 aspects (compatibility, sharing information, responsiveness and quality of relations.

Ebrahim Hajizadeh and et al (2010) found out that effective factors on improving performance of human workforces at Payam Noor University of Golestan province are including: individual motivation with average of 69.4 has the highest influence on improving performance.

Lawson (2006) recommended 4 important factors on Employees empowerment including: 1) Involvement of employees in the decision making process 2) Involvement of employees in the planning process 3) Acknowledgment of employees 4) Offering education and support service of employees continuously

\section{Methodology}

This is descriptive-correlation research by collecting field data. The main reason for selecting this type of methodology was that due to the purpose of the study and also the nature of required data, descriptive-correlation research design was the best possible methodology. Furthermore, the study is an applied research method in that its findings can be practically used in real situations. Statistical society of this research is 175 employees at headquarters of municipality and sampling method is simple random or appointment that by using Cochran formula total number of 120 persons was selected. Dependent research variable is Employees empowerment and independent variable is status of individual, organizational and educational factors. In this study in order to perform theoretical and qualitative studies, it was benefit from documentary method and for quantitative stage, it was benefit from field method.

\section{Results}

\subsection{Descriptive Statistics:}

\subsubsection{Status of Age}

In order to study the status of age of respondents, 6 classes of age were defined that is shown in table 1.

Table 1: Status of age of respondents

\begin{tabular}{|l|c|c|c|c|c|}
\hline Question & \multicolumn{5}{|c|}{ Answer } \\
\hline & Less than 30 & $30-35$ years & $35-40$ years & $40-45$ years & Over 45 years \\
\hline Number & 6 & 27 & 48 & 33 & 6 \\
\hline Percentage & 5 & 22.5 & 40 & 27.5 & 5 \\
\hline
\end{tabular}

\subsubsection{Sex}

$81 \%$ of respondents are male and $19 \%$ are female.(table 2 ).

Table 2: Status of sex of respondents

\begin{tabular}{|c|c|c|c|}
\hline \multicolumn{2}{|c|}{ Question } & \multicolumn{2}{c|}{ Respondents } \\
\hline Sex of respondents & Number & Male & Female \\
\hline & Percentage & 97 & 23 \\
\hline & & 81 & 19 \\
\hline
\end{tabular}




\subsubsection{Marital Status}

116 respondents were married and 4 respondents were single; therefore, more than $96 \%$ of respondents were married and nearly $3 \%$ were single

Table 3: Marital Status of respondents

\begin{tabular}{|c|c|c|c|}
\hline \multicolumn{2}{|c|}{ Question } & \multicolumn{2}{c|}{ Respondents } \\
\hline Marital Status & & Male & Female \\
\hline & Number & 4 & 116 \\
\hline & Percentage & 3.3 & 96.7 \\
\hline
\end{tabular}

\subsubsection{Education}

Most of employees in this study have Bachelor's Degree (51.7\%) and the education of respondents are shown in table 4 that are classified into 5 classes. $11 \%$ of respondents have Diploma of Secondary School and others have higher education; therefore, most of respondents have nearly high education

Table 4: Education of respondents

\begin{tabular}{|c|c|c|c|c|c|c|}
\hline Question & & Answer & & & & \\
\hline & & Diploma & Associate Degree & Bachelor's Degree & Master's Degree & PhD Degree \\
\hline Education & Number & 13 & 2 & 62 & 41 & 2 \\
\hline & Percentage & 10.8 & 1.7 & 51.7 & 33.8 & 1.7 \\
\hline
\end{tabular}

\subsection{Inferential Statistics}

\subsubsection{Kruskal-Wallis one-way analysis of variance}

This test is applied for determining effective factors onEmployeesempowerment of headquarters of municipality of Islamshahr and its results are shown in table 5.

Table 5: Kruskal-Wallis one-way analysis of variance test and comparing indices of empowerment with variable of type of recruitment

\begin{tabular}{|l|c|c|c|}
\hline & Chi-square & Df & Sig \\
\hline Arranged activities & 0.878 & 2 & 0.645 \\
\hline Appropriate salary & 17.764 & 2 & 0.000 \\
\hline Partnership on decision making & 2.078 & 2 & 0.345 \\
\hline Welfare facilities & 12.345 & 2 & 0.002 \\
\hline Order and report & 6.460 & 2 & 0.040 \\
\hline Economic status & 8.767 & 2 & 0.012 \\
\hline Regular supervision & 0.867 & 2 & 0.648 \\
\hline Situation of promotion & 0.985 & 2 & 0.611 \\
\hline Required skill & 3.370 & 2 & 0.185 \\
\hline National attempt & 23.804 & 2 & 0.000 \\
\hline Support & 9.992 & 2 & 0.007 \\
\hline Equipment & 1.337 & 2 & 0.512 \\
\hline Status & 0.318 & 2 & 0.853 \\
\hline Being informed of subsidiary affairs & 4.722 & 2 & 0.94 \\
\hline Experience & 9.682 & 2 & 0.008 \\
\hline Education & 0.855 & 2 & 0.652 \\
\hline Job adaptability & 11.244 & 2 & 0.004 \\
\hline
\end{tabular}

H0: There is no significant relationship between type of recruitment, job adaptability, education, experience, being 
informed of subsidiary affairs, status, equipment, support, financial bonus, required skill, promotion, regular supervision, economic status, order and report, welfare facilities, partnership on making decision, appropriate salary, arranged activities

H1: There is significant relationship between type of recruitment, job adaptability, education, experience, being informed of subsidiary affairs, status, equipment, support, financial bonus, required skill, promotion, regular supervision, economic status, order and report, welfare facilities, partnership on making decision, appropriate salary, arranged activities

Therefore, in relation to variable of job adaptability, experience, support, financial bonus, economic status, order and report, welfare facilities, appropriate salary the zero hypothesis is rejected $(0.05<p)$

Comparing variable of type of recruitment with index of empowerment show that there is significant relationship between job adaptability, experience,support, financial bonus, economic status, order and report, welfare facilities, appropriate salary the zero hypothesis is rejected $(0.05<p)$

\subsection{F-Test}

In order to determine the effective factors onEmployeesempowerment, it was benefit from $\mathrm{F}$ test and its results are shown in table 6.

\begin{tabular}{|c|c|c|c|c|c|c|}
\hline & \multicolumn{2}{|c|}{ Sum of squares } & Df & Mean square & $F$ & Sig \\
\hline \multirow{3}{*}{ Job Adaptability } & Between groups & 53.036 & 2 & 26.518 & 46.384 & 000 \\
\hline & Within groups & 66.889 & 117 & 0.572 & & \\
\hline & Total & 119.925 & 119 & & & \\
\hline \multirow{3}{*}{ Education } & Between groups & 5.670 & 2 & 2.835 & 2.813 & .064 \\
\hline & Within groups & 11.921 & 117 & 1.008 & & \\
\hline & Total & 123.592 & 119 & & & \\
\hline \multirow{3}{*}{ Experience } & Between groups & 24.821 & 2 & 12.411 & 33.174 & 0.000 \\
\hline & Within groups & 43.771 & 117 & 0.374 & & \\
\hline & Total & 68.592 & 119 & & & \\
\hline \multirow{3}{*}{ Being informed of subsidiary affairs } & Between groups & 13.088 & 2 & 6.544 & 17.874 & 0.000 \\
\hline & Within groups & 42.837 & 117 & 0.366 & & \\
\hline & Total & 55.925 & 119 & & & \\
\hline \multirow{3}{*}{ Status } & Between groups & 4.684 & 2 & 2.342 & 4.699 & .011 \\
\hline & Within groups & 58.308 & 117 & .498 & & \\
\hline & Total & 62.992 & 119 & & & \\
\hline \multirow{3}{*}{ Equipment } & Between groups & 5.025 & 2 & 2.587 & 2.587 & .080 \\
\hline & Within groups & 113.642 & 117 & & & \\
\hline & Total & 118.667 & 119 & & & \\
\hline \multirow{3}{*}{ Support } & Between groups & 1.026 & 2 & .513 & .445 & .642 \\
\hline & Within groups & 134.840 & 117 & 1.153 & & \\
\hline & Total & 135.867 & 119 & & & \\
\hline \multirow{3}{*}{ Financial bonus } & Between groups & .575 & 2 & .287 & .299 & .742 \\
\hline & Within groups & 112.592 & 117 & .962 & & \\
\hline & Total & 113.167 & 119 & & & \\
\hline \multirow{3}{*}{ Required skill } & Between groups & 22.110 & 2 & 11.055 & 23.366 & .000 \\
\hline & Within groups & 55.357 & 117 & .473 & & \\
\hline & Total & 77.467 & 119 & & & \\
\hline \multirow{3}{*}{ Promotion } & Between groups & .207 & 2 & .103 & .117 & .890 \\
\hline & Within groups & 103.760 & 117 & .887 & & \\
\hline & Total & 103.967 & 119 & & & \\
\hline \multirow[t]{3}{*}{ Regular supervision } & Between groups & 7.743 & 2 & 3.871 & 5.019 & .008 \\
\hline & Within groups & 90.249 & 117 & .771 & & \\
\hline & Total & 97.992 & 119 & & & \\
\hline
\end{tabular}




\begin{tabular}{|c|c|c|c|c|c|c|}
\hline \multirow{3}{*}{ Economic status } & Between groups & 20.602 & 2 & 10.301 & 15.110 & .000 \\
\hline & Within groups & 79.765 & 117 & .682 & & \\
\hline & Total & 100.367 & 119 & & & \\
\hline \multirow{3}{*}{ Order and report } & Between groups & 5.453 & 2 & 2.726 & 5.035 & .008 \\
\hline & Within groups & 63.348 & 117 & .541 & & \\
\hline & Total & 68.800 & 119 & & & \\
\hline \multirow{3}{*}{ Welfare facilities } & Between groups & .736 & 2 & .368 & .471 & .626 \\
\hline & Within groups & 91.389 & 117 & .781 & & \\
\hline & Total & 92.125 & 119 & & & \\
\hline \multirow{3}{*}{ Partnership in decision } & Between groups & 45.575 & 2 & 22.788 & 23.971 & .000 \\
\hline & Within groups & 111.225 & 117 & .951 & & \\
\hline & Total & 156.800 & 119 & & & \\
\hline \multirow{3}{*}{ Appropriate salary } & Between groups & 23.515 & 2 & 11.757 & 20.125 & .000 \\
\hline & Within groups & 68.352 & 117 & .584 & & \\
\hline & Total & 91.867 & 119 & & & \\
\hline \multirow{3}{*}{ Arrangement of activities } & Between groups & 9.678 & 2 & 4.839 & 9.086 & .000 \\
\hline & Within groups & 62.314 & 117 & .533 & & \\
\hline & Total & 71.992 & 119 & & & \\
\hline
\end{tabular}

Results showed that there is significant relationship between organizational commitment, job adaptability, experience, being informed of subsidiary affairs, status, required skills, regular supervision, economic status, order and report, partnership at decision, appropriate salary.

\section{Conclusion}

Successful managers and organizations require having employees working within framework of human resources and knowledge of managers is among most important issue for obtaining to objectives (Mohades Kasaei 2008).

Results of $\mathrm{F}$ showed that there is significant relationship between organizational commitment and following indices: job adaptability, experience, being informed of subsidiary affairs, status, required skills, regular supervision, economic status, order and report, partnership on decision making, appropriate salary and arranged activity.

In addition, studies by Hajizadeh and et al 2010 and Lawson 2006 showed that regular supervision, economic status, order and report, partnership on decision making, appropriate salary is among most important activities of organization and the present research confirms this issue.

\section{Recommendations}

Whereas abundant number of people (nearly 60\%) of respondents announced that their job is not adapted with their talent, it is recommended to perform feasibility study of appropriate workforces to determine their talent and interest.

Whereas significant respondents in this study (more than 85\%) up to low or medium level announced having received financial bonus for successful completion of tasks, it is recommended to offer required considerations

Whereas more than $80 \%$ of respondents announced having low to medium situation for promotion, it is recommended for managers to observe promotion opportunity for maximum benefit from skills and abilities of their employees

\section{References}

Hajizadeh, Ebrahim, Vanki, Zohreh and Zaeiminpour Kermani Maryam .(2010). Studying influence of retraining managerial skills of nursing managers on empowerment nursing personnel, Scientific and Research Journal of Zanjan University of Medical Sciences, Period 13, issue.50

Talebian, Ahmad Reza and Fatemeh Vafai .(2009). Comprehensive empowerment pattern of human workforces, Quarterly periodical of Tadbir, issue.203

Taherpour, Habibollah, Kalantari, Mohammad Reza and Gholam Reza Moradi .(2010). Studying effective factors on Employees empowerment of South Pars Gas Complex Co. Process of management and development, issue.73

Mohades Kasaei, Soheila .(2008). Studying effective factors on empowerment human workforces at NIOPDC, M.A thesis, Faculty of Management, University of Tehran

Mirkamali, Seyed Mohammad and Naser Nastizaei .(2010). Studying relationship of psychological empowerment and job satisfaction of nursing personnel, quarterly periodical of college of nursing and midwifery of Oruimeh, $8^{\text {th }}$ period, issue 2, page 104-113

Lawson Karen 2006, 4 Key to employee empowerment Lawson consulting group Inc. 